\title{
How Indian Railway affected by COVID-19
}

\section{Pankaj Jain}

Assistant Professor

SGT University,

Gurugram

+91- 9255267199

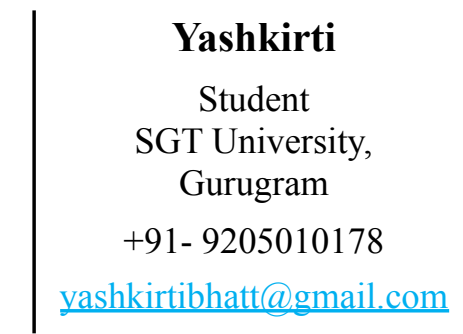

\section{Abstract}

Previously, the World has to meet severe diseases like cholera and Plague. A lot of researchers have researched them and constitute when and how these all diseases have been spread in the world. Reason for most diseases found and vaccines have made. Corona has been declared a Global Pandemic and has drastically affected the condition of almost all the countries of the world. Illness, specific health-related behavior, or other health-related events in a community or region are known as epidemics when they exceed normal expectancy. - The WHO Coronavirus (COVID-19) became known in 2019. All other diseases were affecting the health of human being only. But Coronavirus disease affects our economy also. The major impact of the coronavirus was on our Indian Railway.

COVID-19 virus has been spreading rapidly in India since March 2020. The Government of India decided for a total of 21 days of a lockout in India by 24 March 2020. All trains are suspended for an unspecified time due to the lockdown announced by the Government of India. The revenue of the railways was shut down due to the affected Indian Railways passenger traffic and low fear income due to the lockdown. And spending continued to increase on maintenance, security, and depreciation. The current crisis period is unknown. The hospital did not have enough ventilators during COVID-19 so the railways began to convert train trainers into portable ventilators. The whole world is in the most pandemic situation ever on earth. Millions of people have fallen victim to this deadly disease. We don't even know how long it will still last.
I think the negative effect is more. Many such changes are taking place around the world.

\section{Introduction}

Due to COVID-19, all passenger trains were suspended until May 31, 2020. However, freight services continued in various parts of the country with trains carrying essential goods.

Railways had also provided railway parcel vans for speedy mass transportation for customers including e-commerce institutions and state governments for transportation of certain goods. This includes treatment, medical equipment, food, etc. This includes treatment, medical equipment, food, etc. in small parcel sizes. Apart from these, the Railways had taken several other steps to assist with the epidemic.

\section{How Restricted Travel affected Railway's Internal Revenue.}

As the travel ban extended from 23 March to 31 May 2020, it affected the railways' finances for both 2019-20 and 2020-21.

Railways generate internal revenue mainly from passenger and freight traffic. In 2018-19, passenger traffic and freight accounted for about $27 \%$ and $67 \%$, respectively, in internal revenue. The remaining amount is earned from other miscellaneous sources such as parcel service, coaching receipts, and platform ticket sales. In $2020-21$, the railway expects to earn $27 \%$ of its internal revenue from passenger traffic and $65 \%$ from freight.

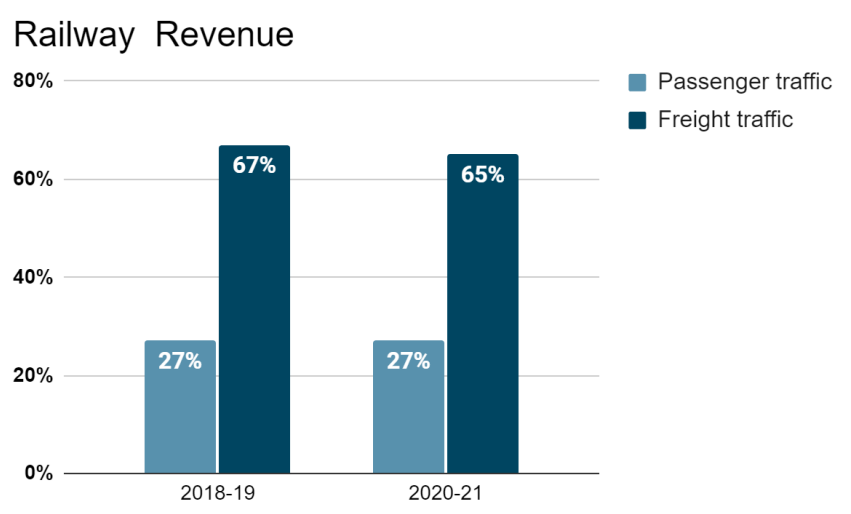




\section{Freight Result}

In 2020-21, the railways are expected to earn Rs $1,47,000$ crore from freight traffic, which is $9 \%$ higher than the revised estimates of 2019-20 i.e.Rs 1,34,733 crore. According to data provided by the Ministry of Railways, as of December 2020, freight revenue was approximately Rs $1,24,184$ crore, which is expected to come through the loading of goods in 2020-21. This is Rs 22,816 crore less than the 2020-21 revised estimate of freight revenue. This means that to meet the revised estimate targets (15\% of the year target), freight from January to March 2021 would have to be generated at Rs 22,816 crore.

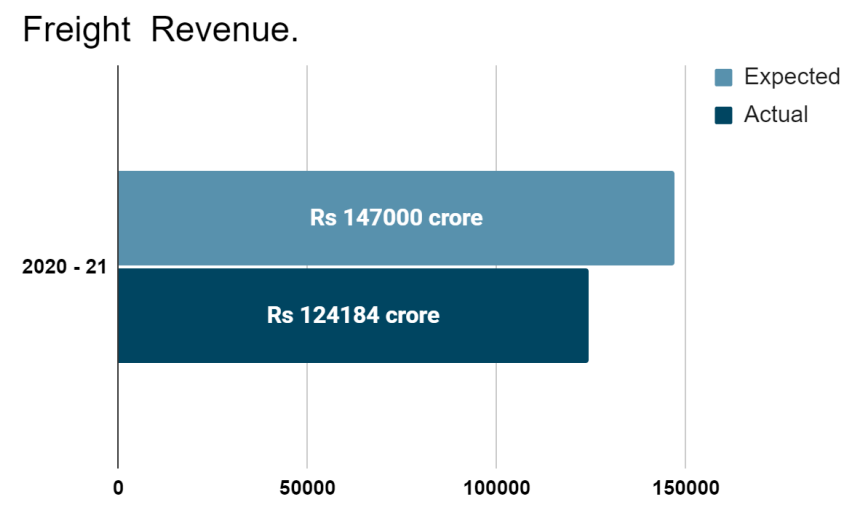

However, the average freight revenue in 2020-21 (for 9 months) has been around Rs 13,798 crore. Freight receipts for 2022 are pegged at Rs 1,34610 crores, as compared to Rs 1,24,14 crores expected to come through shipments of goods in 2021. Passenger receipts for 2021 have been revised upwards to Rs 15,000 crore against the budget estimate of Rs 61,000 crore, as passenger train services were suspended for most of the current financial year.

While passenger traffic was completely restricted, freight traffic was underway. The operation of railways for transportation of essential goods, relief and evacuation, and their respective operational organizations was permitted under lockdown. Many goods (coal, iron ore, steel, petroleum products, food grains, fertilizers) brought by the railways were declared essential goods.
Railways had started operating special parcel trains (for essential, e-commerce goods, etc.) since lockdown. These activities helped to continue the generation of freight revenue. However, some goods transported by the railways, such as cement, which contribute about $8 \%$ of the railways' freight revenue, were not classified as essential goods. Railways had also waived some of the charges on freight.

\section{Passenger Movement}

In 2020-21, the railway is expected to earn Rs 61,000 crore from passenger movement, which is $9 \%$ higher than the revised estimate of 2019-20 (Rs 56,000 crore). According to data provided by the Ministry of Railways, passenger traffic revenue up to December 2021 was Rs. 36,993.82 crores as compared to the same period of the previous year. This means that from January to March 2021 this amount has to be generated to meet the revised estimate targets $(60 \%$ of the year's target).

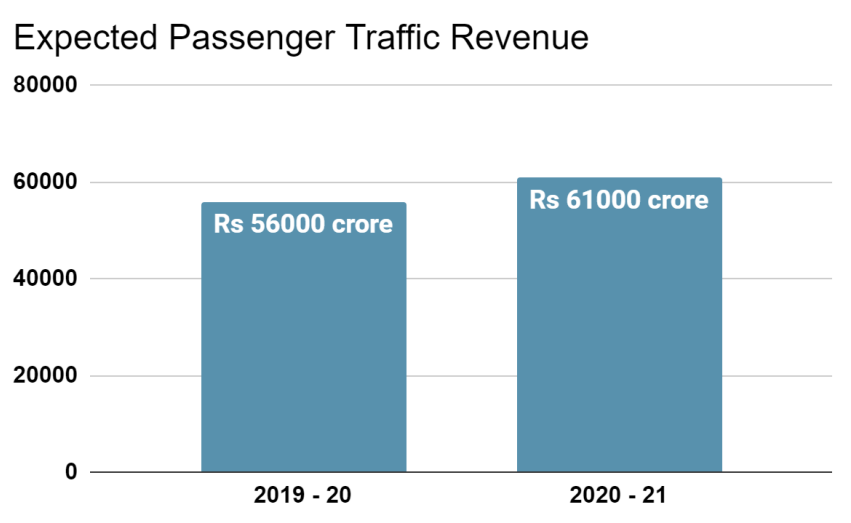

However, the average passenger revenue in 2020-21 (for 9 months) has been around Rs 2,667 crore. Let us inform you that the passenger revenue in February 2020 was Rs 4,480 crore. The railways are expecting a fall in the 2019-20 passenger revenue as traveling is completely banned from March 23

It was not clear when travel across the country would resume for business as usual. Some states had started increasing the lockdown in their state.

Freight, cross-subsidizing

passenger Movement. 
Freight had cross-subsidizing passenger traffic I.e. The Railways uses the profits from its freight business to offset such losses in the passenger segment, and also to manage its overall financial condition. Such cross-subsidies have resulted in higher freight tariffs.It may worsen this year

Restrictions on passenger travel and lockdown caused more damage to passenger operations. This increased the cross-subsidy burden on freight. For example, in 2017-18, passengers and other train services incurred losses of Rs 37,937 million, while goods made a profit of $\$$ 39,956. About $95 \%$ of the proceeds from these supplies were used to compensate for the loss of passengers and other train services. And about Rs. 46,280 crore was the passenger revenue during that period. This means that the loss in the passenger business is about 82 percent of its revenue.

\section{Expenditures of Railway}

While there is a restriction on traveling, railways cannot run all their services. It still has to spend a lot of its operating expenses. Employees' salaries and pensions are to be paid and this is $66 \%$ of the total revenue expenditure of the Railways. Between 2015 and 2020 (budget estimates), railway spending on salaries grew at an average annual rate of $13 \%$. About $18 \%$ of the revenue expenditure is on fuel expenditure, but it may see some decline due to the fall in oil prices.

Railways will also have to continue spending on maintenance, security, and depreciation as these are long-term costs that cannot be overcome. In addition, regular maintenance of railway infrastructure will be required for freight operations.

\section{$\underline{\text { Surplus revenue and operating ratio }}$}

The surplus of a railway is calculated as the difference between its total internal revenue and its revenue expenditure (this includes working expenses and appropriation of pension and depreciation funds). Operating Ratio is the ratio of operating expenses (expenses arising out of the day-to-day operation of railways) to revenue earned from traffic. Therefore, a high ratio indicates poor ability to generate a surplus that can be used for capital investment such as laying new lines or deploying more coaches. The decline in revenue surplus affects the railway's ability to invest in infrastructure.

Over the last decade, railways have struggled to generate more surpluses. As a result, the operating ratio has consistently exceeded $90 \%$. In 2018-19, this ratio deteriorated from an estimated ratio of $92.8 \%$ to $97.3 \%$. The CAG (2019) had noted that if the 2018-19 advances are not included in the receipts, the operating ratio for $2017-18$ would have been $102.66 \%$. In 2020-21, the railway is expected to generate a surplus of Rs 6,500 crore and maintain an operating ratio of $96.2 \%$. This surplus may decline further, and the operating ratio may deteriorate, with revenue generation being affected by the lockdown.

\section{Other sources of Revenue}

Apart from its internal resources, Railways has two other primary sources of financing:

(i)Budgetary support from the central government,

(ii)Additional budgetary resources mainly borrowings but also institutional financing, public-private partnerships, and direct foreign investment are included.

\section{Central government Budgetary support}

The central government helps the railways to expand their network and invest in capital expenditure. Gross budgetary support of Rs 70,250 crore is proposed from the central government in 2020-21. This is 3\% higher than the revised figures for 2019-20 (Rs 68,105 crore). Note that due to the COVID epidemic, government revenue is also being affected, this amount can also change during the year. 


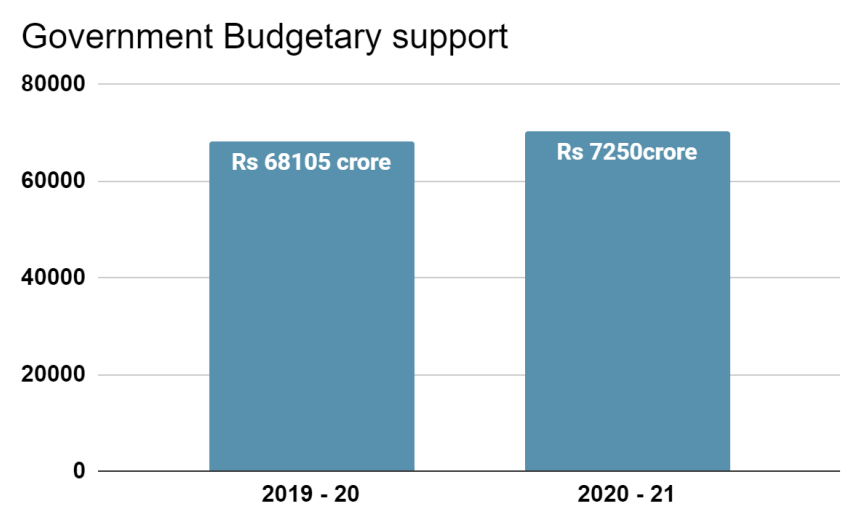

\section{Borrowings}

Railways mostly borrow money through the Indian Railway Finance Corporation (IRFC). IRFC borrows money from the market (through the issuance of taxable and tax-free bonds, term loans from banks and financial institutions), and then follows a leasing model for financing the rolling stock assets and project assets of the Indian Railways.

In the last few years, there has been a rapid increase in the borrowing of railways to bridge the gap between available resources and expenditure. Earlier, the bulk of the capital expenditure of the railways was met with budgetary support from the central government. In 2015-16, this trend changed with the Railways meeting most of its capital expenditure through additional budgetary resources (EBR). In 2020-21, it is evaluated to increase Rs 83,292 crore through EBR, which is slightly higher than the evaluated amount of 2019-20 i.e.Rs 83,247 crores.

Note that both these sources are mainly used for the capital expenditure of railways. Another portion of central government funding is being used to compensate for the loss of railway lines and IRCTC for the cost of e-ticketing operations (Rs 2,216 crore in the 20-21 budget). If the revenue receipts of the railways decline this year, it may require additional assistance from the central government to finance its revenue expenditure or to finance it through its borrowings.

However, the increasing dependence on lending may worsen the financial condition of the railways. Over the past few years, the growth of both rail-based freight and passenger traffic has declined and this has affected the railways' income from its core business. The decline in revenue growth will affect the transporter's ability to pay its debts in the future.

\section{Social service by Railways}

Apart from running goods trains, the Railways was also undertaking several other tasks to help tackle the pandemic. For example, the railway's construction capacity was being used to help combat COVID-19. The production facilities available with the railways were being used to manufacture items such as PPE gear.

The railway was also exploring how to use its existing manufacturing facilities to make simple beds, medical trolleys, and ventilators. Railways have also started providing cooked food in bulk to those in need, where IRCTC has its base kitchen. The transporter also opened its hospitals for COVID patients.

As of April 6, 2020, 2,500 train coaches were replaced as isolation coaches. On average 375 coaches were being converted in 133 places in the country on a single day. Indian Railways was severely affected since the COVID-19 pandemic disrupted services in 2020, which stalled for a few months. In December 2020, the government announced the draft National Rail Scheme. The 2022 budget may include allocations and proposals to supplement the scheme. "The National Rail Scheme aims to increase initial investment by 2030 to build pre-demand capacity and increase the freight share by 45 percent," the railway ministry said in a statement.

\section{References}

- https://www.prsindia.org/theprsblog/examini ng-urban-local-governance-india-through-ca se-bengaluru

- https://economictimes.indiatimes.com/indus try/transportation/railways/railways-looks-to -monetise-dedicated-freight-corridors/article show/80637802.cms?utm_source $=$ contentof 
interest\&utm_medium=text\&utm_campaign $=$ cppst

- https://economictimes.indiatimes.com/ind ustry/transportation/railways/railways-lo oks-to-monetise-dedicated-freight-corrido rs/articleshow/80637802.cms

- https://www.businesstoday.in/current/econo my-politics/railways-revenue-declined-by-rs -36993-crore-in-2020-due-to-pandemic-govt /story/430283.html 